\section{ASTRONOMICAL PHENOMENA FOR THE WEEK 1887 DECEMBER 25-3I.}

(FOR the reckoning of time the civil day, commencing at Greenwich mean midnight, counting the hours on to 24 , is here employed.)

\section{At Greenwich on December 25}

Sun rises, $8 \mathrm{~h} .7 \mathrm{~m}$.; souths, $12 \mathrm{~h}$. Om. $14^{\circ} 9 \mathrm{~s}$.; sets, $15 \mathrm{~h} .53 \mathrm{~m}$. : right asc. on meridian, $18 \mathrm{~h} .15^{\circ} \mathrm{om}$. ; decl. $23^{\circ} 24^{\prime} \mathrm{S}$. Sidereal Time at Sunset, $22 \mathrm{~h} .8 \mathrm{~m}$.

Moon (Full on December 3o, 8h.) rises, I3h. $32 \mathrm{~m}$. ; souths, 2oh. $3 \mathrm{Im}$. ; sets, $3 \mathrm{~h} .4 \mathrm{Im} .^{*}$ : right asc. on meridian, 2h. $46^{\circ} 7 \mathrm{~m}$.; decl. $10^{\circ} 40^{\prime} \mathrm{N}$.

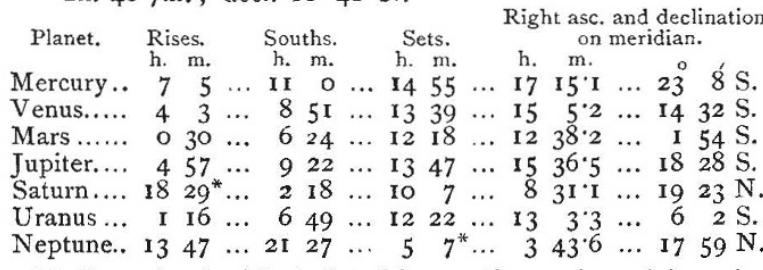

* Indicates that the rising is that of the preceding evening and the setting that of the following morning.

Occultations of Stars by the Moon (visible at Greenwich).

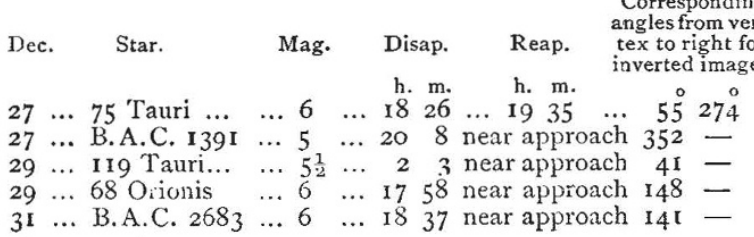
$\begin{array}{ccccc}\text { Dec. } & & \text { h. } & & \\ 26 & \ldots & 8 & \text {... } & \text { Mars at greatest distance from the Sur. }\end{array}$

$$
\begin{array}{ll}
\text { Variable Stars. } \\
\text { Star. }
\end{array}
$$

U Cephei $\quad \ldots \quad \ldots \quad 0_{52} \cdot 3 \ldots 8$ i 16 N. ... Dec. $26,23 \quad 24 m$

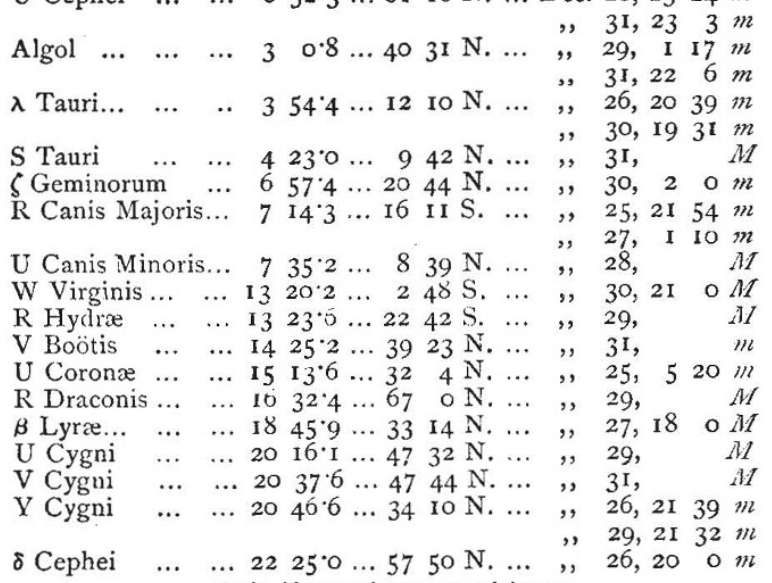

$$
M \text { signifies maximum; } m \text { minimum. }
$$

$$
\text { Meteor-Showers. }
$$

$$
\text { R.A. Decl. }
$$

Near $\delta$ Aurigx ... ... $92^{\circ} \quad \ldots \quad 56^{\circ} \mathrm{N} . .$. Slow ; bright. , $\zeta$ Ursæ Majoris. $200 \quad \ldots .57$ N. ... Slow.

\section{THE U.S. COMMISSION OF AGRICULTURE. ${ }^{1}$}

"RESOLVED by the Senate and House of Representatives of the United States of America, in Congress assembled, That there be printed 310,000 copies of the Annual Report of the Coumisioner of Agriculture for the year 1885; x " Report of the Commission of Agriculture, 1885." (Washington Government Printing-Office.)
200,000 for the use of the Members of the House of Representatives, 80,000 for the use of the Members of the Senate, and 30 , oco copies for the use of the Department of Agriculture.

"Sec. 2. That the sum of 200,000 dollars is hereby appropriated out of money in the Treasury to defray the cost of the publication of the said Report."

If the British Government desires to assist poor languishing agriculture, it would be well for it to look across the Atlantic Ocean for suggestions as to possible action. A "Commissioner of Agriculture" and an Annual Report from him is in itself enough to arrest attention. The very gilt letters on the back of this volume supply a text upon which a profitable and edifying sermon might be preached. The subject-matter of the Report, its practical or unpractical nature, the sort of topic handled, and the manner of their handling, all ought to arouse curiosity in the minds of those who doubt the utility of Commissions, and prefer laissez faire to stirring up with the long pole.

A more scattered flock than the agriculturists of Great Britain it would be difficult to find. Sheep without a shepherd, soldiers without a leader, a fleet without sailing orders, are the metaphor we should use if it were our purpose to portray their presen: condition. It is not so in America. There the interests of agriculture are watched by a Department of Agriculture, and the splendid Report of the proceedings of this Department serve. as a mouth-piece of the whole agricultural community, and exer cises the functions of a heart in keeping up a healthy circulation of knowledge and a brain in receiving impressions from all parts of the body agricultural. No wave of pleasurable sensation aris ing from salubrity of climate or rise of values but causes a smilin: paragraph. No twinge of pain caused by insect attack or disease but is at once chronicled and investigated in this excellent Department. The cost is all defrayed by the Government, who are not afraid to spend 200,000 dollars on the mere publication of the Report. Whether the Report is worth the immense sums of money that its material with the large staff of persons employed in collecting the same must have cost is a question of much importance, and not altogether easy to answer. One thing, however, we may be certain of : that if it pays the American Government to undertake the investigation of problems connected with the productive powers of Nature, still more would it pay us with our complicated agriculture and extensive system of cultivation. It might be said in extenuation of our supineness with regard to agricultural science that we have an Agricultura Department of the Privy Council. So far as this Department may prove a nucleus for further expansion it is good, but we cannot conceal from ourselves the narrowness of the scope of our Agricultural Department as compared with the breadth of the aims and objects of the American Agricultural Department. The energies of our Department are chielly devoted to what is included in the Report before us as the Bureau of Animal Industry, but with this great difference : the English Agricultural Department deals chiefly with inspecting and regulating the ports of debarkation, reporting on outbreaks, and proclaiming infected districts. It is intimately connected with and assisted by the police. The American Bureau of Animal Industry deals in rules and regulations for the suppression and extirpation of contagious diseases, but in addition spends large sums upon investigations into the nature, causes, and remedies of diseases. Its Reports are replete with information as to liquid cultures of the Bacterium of swine fever and other diseases. The American Government have not only set themselves the task of preventing the spread of disease, but are doing excellent work in tracking diseases of all sorts to their source, with a fair and improving prospect of being able to stop their devastations at the fountainhead. Not only is this the case with regard to the diseases of animals, but also of plants, under the sections respectively headed "Report of the Botanist" and "Report of the Microscopist."

Before endeavouring to lay before the readers of NATURE any of the facts recorded in this deeply interesting volume, I will mention the various sections under which information is collected and investigations are prosecuted, feeling confident that by so doing I shall show the many sides from which agriculture obtains direct assistance from the progress of pure science. First in order stands the Report of the Superintendent of Gardens and Grounds, containing valuable information upon mildews and blights, the peach-leaf blister, cracking of pears, and the potato-disease. Next comes the Report of the Chief of the Seed Division, dealing with crossing and hybridization, the production of new varieties of wheat by cross-fecundation, improvement by selec- 